Studia nad Autorytaryzmem i Totalitaryzmem 42, nr 2

Wrocław 2020

https://doi.org/10.19195/2300-7249.42.2.3

BARTŁOMIEJ KRZAN

ORCID: 0000-0003-3964-114X

Uniwersytet Wrocławski

bartlomiej.krzan@uwr.edu.pl

\title{
Celowość kodyfikacji zbrodni przeciwko ludzkości przez Komisję Prawa Międzynarodowego ONZ
}

\begin{abstract}
Abstrakt: Tekst podejmuje analizę przyjętego w 2019 roku przez Komisję Prawa Międzynarodowego projektu artykułów dotyczących zapobiegania i karania zbrodni przeciwko ludzkości, a także rozważa rolę Komisji w zakresie kodyfikacji norm międzynarodowego prawa karnego. W przeciwieństwie do zbrodni ludobójstwa i zbrodni wojennych zbrodnie przeciwko ludzkości nie zostały skodyfikowane pod koniec lat czterdziestych ubiegłego stulecia. Brak odrębnej regulacji jest problemem pomimo przyjęcia w 1998 roku statutu Międzynarodowego Trybunału Karnego. Zasadne jest zatem rozważenie potrzeby ujęcia zbrodni przeciwko ludzkości w odrębnej konwencji.

Tematyka ta była obecna już w trakcie wcześniejszych prac Komisji. Pomimo rozczłonkowanej regulacji, obejmującej oddzielnie szczegółowe refleksy zbrodni przeciwko ludzkości, jak apartheid, tortury czy wymuszone zaginięcia, można przyjąć, że rdzeń definicji zbrodni przeciwko ludzkości jest dobrze zakotwiczony w międzynarodowym prawie zwyczajowym, nawet jeśli brakuje zgody co do szczegółowych kwestii. Podejmowane w ramach KPM rozważania równie dobrze mogą przysłużyć się pracom nad stworzeniem bardziej ogólnej konwencji poświęconej zbrodniom międzynarodowym.

Analiza projektu artykułów przyjętych w 2019 roku potwierdza zasadniczy brak konfliktów z zobowiązaniami państw wynikającymi z aktów ustanawiających trybunały międzynarodowe, zarówno stały MTK, jak i trybunały hybrydowe o mieszanej, międzynarodowo-krajowej jurysdykcji i składzie. Zawarta w art. 2 definicja zbrodni przeciwko ludzkości powtarza analogiczną treść ujętą w art. 7 statutu rzymskiego. Prace Komisji zdają się dopełniać prace nad częścią materialną międzynarodowego prawa karnego. Projekt artykułów przyczynia się też do implementacji zasady komplementarności wynikającej ze statutu rzymskiego. Centralnym zamysłem kodyfikacji było przede wszystkim podbudowanie prawodawstwa wewnętrznego i odnośnej działalności sądów krajowych oraz ustanowienie ram współpracy w zakresie ekstradycji oraz pomocy prawnej.

Nieistnienie normy traktatowej nie jest bezwzględną przeszkodą dla pociągnięcia do odpowiedzialności na gruncie prawa międzynarodowego. Podstawy do tego może przecież dostarczać międzynarodowe prawo zwyczajowe. Oczywiście związana z nim niewystarczająca precyzja wywołuje wiele problemów, przede wszystkim ze względu na zasadę legalizmu ścigania karnego.

W opracowaniu odniesiono się także do negatywnego wymiaru kodyfikacji. Wybór metody traktatowej bywa niekiedy uznawany za otwarcie drogi do kwestionowania ustaleń dokonanych
\end{abstract}


w konwencji, a przez to osiągnięcie zupełnie odwrotnego od zamierzonego skutku. Ale nawet pozostawienie kodyfikacji jako niewiążącego instrumentu ma znaczenie do ustalenia rozumienia prawa międzynarodowego na podobieństwo kodyfikacji traktatowej. Niezależnie od ostatecznej formy działalności KPM formułowanie i usystematyzowanie norm w wersji pisemnej jest przedsięwzięciem, które zapewnia postęp w prawie. Przez wzmocnienie jego pewności i okazję do wyjaśnienia i rozwijania istniejących już norm, ale też wykrystalizowanie kodyfikowanych reguł w jedną szczegółową formułę może być przeszkodą dla przyszłego rozwoju prawa i jego responsywności względem potrzeb społeczności międzynarodowej.

Słowa kluczowe: kodyfikacja, zbrodnie przeciwko ludzkości, Komisja Prawa Międzynarodowego ONZ.

\title{
DESIRABILITY OF CODIFYING CRIMES AGAINST HUMANITY BY THE UN INTERNATIONAL LAW COMMISSION
}

\begin{abstract}
The present paper analyses the Draft articles on Prevention and Punishment of Crimes Against Humanity, adopted by the International Law Commission in 2019 and considers the respective role by the Commission in codifying international criminal law. Contrary to genocide and war crimes, crimes against humanity were not codified in the late 1940s. The lack of treaty regulation may be considered problematic, even despite the adoption in 1998 of the Rome Statute of the International Criminal Court. Therefore, it may be noteworthy to consider the desirability of adopting a separate convention on crimes against humanity.

The topic has already been tackled in other activities of the Commission. Despite the fragmented regulation covering separate particular reflections of the crimes against humanity, such as apartheid, torture or enforced disappearances, it is justified to claim that the core of the crimes against humanity is firmly rooted in international customary law, even if some respective specific questions remain disputable. Considerations undertaken by the ILC may as well prove helpful in establishing a more general convention concerning international crimes.

The analysis of the ILC Draft Articles confirms the conformity with obligations arising for states out of the instruments creating international criminal courts and tribunals (including those of mixed hybrid character combining international and domestic elements of jurisdiction and composition). The Article 2 definition reflects the analogous provision of the Rome Statute as contained in its Article 7. The activities of the ILC seem to complement the substantive part of international criminal law. The 2019 Draft Articles contribute to the implementation of the principle of complementarity, as arising out of the Rome Statute. The main goal of the codification is a development of national laws that prohibit and punish crimes against humanity and the respective domestic judiciary's actions, as well as to establish the framework of cooperation in terms of extradition and judicial assistance.

The lack of a treaty framework does not necessarily impose a cogent bar to prosecution under international law as the latter may be of course based on international custom. The associated lack of sufficient precision may prove problematic, first of all because of the legality principle.

Finally, the paper also deals with a negative dimension of codification. Choosing a treaty method may be treated as a means to allow undermining its negotiated provisions. But even a reliance on a non-binding instrument may remain meaningful to establish and ascertain the respective norms of international law, similar to a codification treaty. Irrespective of the eventual outcome of the ILC Draft Articles any formulation and systematic consideration of norms in a written form is a welcome enterprise allowing for a legal development, through increasing certainty of law and offering yet
\end{abstract}

Studia nad Autorytaryzmem i Totalitaryzmem 42, nr 2, 2020

(C) for this edition by CNS 
another occasion to clarify and develop the existing normative framework. However, reducing the crystallization process to a single particular formula may as well prove destructive for future legal development and its responsiveness to the needs of the international community.

Keywords: codification, crimes against humanity, UN International Law Commission.

\section{Wprowadzenie}

Przyjęcie przez Komisję Prawa Międzynarodowego (KPM) w 2019 roku w drugim czytaniu projektu artykułów na temat zapobiegania i karania zbrodni przeciwko ludzkości ${ }^{1}$ daje doskonały asumpt nie tylko do bliższego spojrzenia na odnośny dokument, lecz także do analizy prac organu pomocniczego Zgromadzenia Ogólnego ONZ, od samego początku zaangażowanego w rozwój międzynarodowego prawa karnego ${ }^{2}$. Nie ulega wątpliwości, że zbrodniom przeciwko ludzkości przypadł inny los aniżeli zbrodni ludobójstwa czy zbrodniom wojennym, które zostały skodyfikowane pod koniec lat czterdziestych ubiegłego stulecia. Nieistnienie odpowiedniej kodyfikacji rzuca się zatem cieniem, którego do końca nie rozświetla przyjęcie w 1998 roku statutu rzymskiego ${ }^{3}$, chociażby ze względu na ograniczone poparcie dla stałego Międzynarodowego Trybunału Karnego (MTK). Pociąganie do odpowiedzialności jednostek za zbrodnie przeciwko ludzkości jest obecnie oczywiście o wiele mniej kontrowersyjne aniżeli po II wojnie światowej, ale nadal wywołuje wiele szczegółowych wątpliwości, ujawnionych chociażby przy okazji działań kodyfikacyjnych KPM.

W naturalny sposób niniejsze rozważania podejmują kwestię potrzeby ujmowania zbrodni przeciwko ludzkości w odrębnej konwencji. Celem opracowania jest krytyczna ocena zasadności podjęcia tego tematu oraz wypracowanych przez KPM rozwiązań.

\section{Zbrodnie przeciwko ludzkości}

Wprowadzenie kategorii zbrodni przeciw ludzkości oznacza przełamanie kardynalnej zasady prawa międzynarodowego, że stosunki między państwem a jego obywatelami są sprawą wewnętrzną państwa i mogą być kształtowane

${ }^{1}$ Draft articles on Prevention and Punishment of Crimes Against Humanity, adopted by the International Law Commission at its seventy-first session, in 2019, and submitted to the General Assembly as a part of the Commission's report covering the work of that session (A/74/10), 2019, https://legal.un.org/docs/?path=../ilc/texts/instruments/english/draft_articles/7_7_2019.pdf\&lang=EF (dostęp: 30.12.2019).

2 R. O'Keefe, The ILC's contribution to international criminal law, „German Yearbook of International Law" 49, 2006, s. 201.

3 Dz.U. z 2003 r. Nr 78, poz. 708. 
w sposób nieskrępowany, a jakakolwiek ingerencja w wewnętrzne sprawy kraju jest niedopuszczalna ${ }^{4}$. $Z$ tego też powodu należy zauważyć podwójne niebezpieczeństwo związane ze zbrodniami przeciwko ludzkości: zarówno dla jednostek z powodu braku ścisłego sformułowania zarzutów, jak i dla państw, jako że dostarcza pretekstu do mieszania się w sprawy wewnętrzne państw słabszych ${ }^{5}$.

Nie ulega wątpliwości, że powszechne prawo międzynarodowe nie wypracowało jednej precyzyjnej definicji zbrodni przeciwko ludzkości ${ }^{6}$. Niemniej jednak termin ten nie jest zupełnie nowy. W swoim wykładzie haskim Jean Graven stwierdził wręcz, że zbrodnie przeciwko ludzkości są tak stare jak sama ludzkość ${ }^{7}$. Podobnymi sformułowaniami posługiwali się już Voltaire i Beccaria ${ }^{8}$. Nawiązania do praw ludzkości zawarto w deklaracji petersburskiej z 1868 roku w sprawie pocisków wybuchających małego kalibru ${ }^{9}$. Z kolei w preambule IV konwencji haskiej o prawach i zwyczajach wojny lądowej nawiązano do pragnienia służenia interesom ludzkości i wzrastającym wymaganiom cywilizacji ${ }^{10}$, a także zawarto klauzulę Martensa ${ }^{11}$, którą powtórzono za I konwencją haską o prawach wojny z 1899 roku. Mocniejsze nawiązanie zawarto w deklaracji z 28 maja 1915 roku, w której rządy Francji, Rosji i Wielkiej Brytanii określiły masakry ludności ormiańskiej w Turcji jako „zbrodnie przeciwko ludzkości i cywilizacji, za które

${ }^{4}$ J. Waszczyński, Zbrodnie przeciw ludzkości: narodziny i rozwój pojęcia, „Palestra” 30, 1986, nr 10-11 (346-347), s. 63.

${ }^{5} \mathrm{H}$. Donnedieu de Vabres, Le jugement de Nuremberg et le principe de la légalité des délits et des peines, „Revue de Droit Pénal et de Criminologie” 26, 1947, nr 10, s. 833. Nie traci na aktualności spojrzenie polskich autorów, którzy traktowali narodziny pojęcia „zbrodnia” jako „kompromis między niezwykle palącą potrzebą karania sprawców prześladowań rasowych, religijnych, narodowościowych i politycznych, którzy nie byli zbrodniarzami wojennymi w ścisłym tego słowa znaczeniu, a oporem wynikłym z wysoce drażliwej konieczności naruszenia w związku z tym suwerenności prawnej państwa w zakresie dowolnego regulowania na swym obszarze statusu osób tam zamieszkałych" - T. Cyprian, J. Sawicki, Prawo norymberskie. Bilans i perspektywy, WarszawaKraków 1948, s. 287.

6 M. Płachta, Międzynarodowy Trybunat Karny, Kraków 2004, s. 381.

7 J. Graven, Les Crimes contre l'Humanité, „Recueil des Cours de l'Académie de Droit International" 76,1950, s. 433.

8 Zob. W. Schabas, Unimaginable Atrocities: Justice, Politics and Rights at the War Crimes Tribunals, Oxford 2012, s. 51-52.

9 Tekst w: K. Kocot, K. Wolfke, Wybór dokumentów do nauki prawa międzynarodowego, Wrocław-Warszawa 1976, s. 337.

${ }^{10}$ Konwencja dotycząca praw i zwyczajów wojny lądowej (Dz.U. z 1927 r. Nr 21, poz. 161), ust. 2 preambuły.

${ }^{11}$ Ibidem, ust. 8 preambuły: „Zanim bardziej wyczerpujący kodeks praw wojennych będzie mógł być ułożonym, Wysokie Układające się Strony uważają za właściwe skonstatować, że w wypadkach, nieobjętych przepisami obowiązującemi, przyjętemi przez nie, ludność i strony wojujące pozostają pod opieką i władzą zasad prawa narodów, wypływających ze zwyczajów, ustanowionych między cywilizowanemi narodami, oraz z zasad humanitarności i wymagań społecznego sumienia”.

Studia nad Autorytaryzmem i Totalitaryzmem 42, nr 2, 2020

(C) for this edition by CNS 
wszyscy członkowie rządu Turcji będą pociągnięci do odpowiedzialności wspólnie ze sprawcami tych masakr"12.

Zbudowanie fundamentów prawnych umożliwiających ukaranie zbrodni przeciwko ludzkości popełnionych w trakcie II wojny światowej powierzono Komisji Narodów Zjednoczonych do Spraw Zbrodni Wojennych (United Nations War Crimes Commission). Porozumienie londyńskie w przedmiocie ścigania i karania głównych przestępców wojennych Osi Europejskiej z 8 sierpnia 1945 roku ${ }^{13}$ przewidywało $\mathrm{w}$ art. VI, że w kognicji Międzynarodowego Trybunału Wojskowego znalazły się — oprócz zbrodni przeciw pokojowi i zbrodni wojennych — także:

zbrodnie przeciw ludzkości, mianowicie: morderstwa, wytępianie, obracanie ludzi w niewolników, deportacja i inne czyny nieludzkie, których dopuszczono się przeciwko jakiejkolwiek ludności cywilnej, przed wojną lub podczas niej, albo prześladowania ze względów politycznych, rasowych lub religijnych przy popełnianiu jakiejkolwiek zbrodni wchodzącej w zakres kompetencji Trybunału lub w związku z nią, niezależnie od tego, czy było to zgodne, czy też stało w sprzeczności z prawem kraju, w którym zbrodni dokonano.

Trudno określić, w jaki dokładnie sposób określenie to znalazło się w tekście statutu MTW ${ }^{14}$. W protokole negocjacji nad tekstem karty norymberskiej Robert Jackson, główny oskarżyciel z ramienia USA, odnosząc się do listy zbrodni, przyznał, że taki kształt został mu zaproponowany przez ważnego prawnika internacjonalistę ${ }^{15}$. Sam Jackson nie wskazał go z imienia i nazwiska, ale dość powszechnie uznaje się ${ }^{16}$, że za sformułowaniem stał Hersch Lauterpacht, z którym Jackson odbył wiele konsultacji ${ }^{17}$. Należy też w tym miejscu wspomnieć, że początkowo przedstawiciele ZSRR starali się ograniczyć zbrodnie przeciwko

12 E. Schwelb, Crimes against humanity, „British YearBook of International Law” 23, 1946, s. 181.

13 Porozumienie zostało zawarte między Rządem Zjednoczonego Królestwa, Rządem USA, Rządem Tymczasowym Republiki Francuskiej i Rządem ZSRR. Strona polska przystąpiła do porozumienia 25 września 1945 roku, a ratyfikowała 25 czerwca 1947 roku (Dz.U. z 1947 r. Nr 63, poz. 367).

14 D. Luban, A theory of crimes against humanity, „Yale Journal of International Law” 29, 2004, s. 86; R.S. Clark, Crimes against humanity at Nuremberg, [w:] The Nuremburg Trial and International Law, red. G. Ginsburgs, V.N. Kudriavtsev, The Hague 1990, s. 195-196.

15 Zob. Report of Robert H. Jackson United States Representative to the International Conference on Military Trials, London 1945, s. 416.

16 Zob. W. Schabas, op. cit., s. 51; szerzej zob. K. von Lingen, Defining crimes against humanity: The contribution of the United Nations War Crimes Commission to international criminal law, [w:] Historical Origins of International Criminal Law, t. 1, red. M. Bergsmo et al., Brussels 2014, s. 477; L.N. Sadat, Towards a new global treaty on crimes against humanity, [w:] For the Sake of Present and Future Generations: Essays on International Law, Crime and Justice in Honour of Roger S. Clark, red. S. Linton, G. Simpson, W.A. Schabas, Leiden-Boston 2015, s. 313.

17 E. Lauterpacht, The Life of Hersch Lauterpacht, Cambridge 2010, s. 271-272. 
ludzkości do czynów o charakterze faszystowskim i rasistowskich, tak by skierować uwagę wyłącznie na działania Trzeciej Rzeszy ${ }^{18}$.

W dalszej kolejności 20 grudnia 1945 roku Rada Kontroli Niemiec wydała ustawę nr 10, będącą podstawą do ścigania zbrodniarzy wojennych i sprawców podobnych przestępstw, którzy nie podlegali kompetencji MTW. Jej art. 2 odpowiadał analogicznemu przepisowi (art. 6) statutu trybunału norymberskiego, choć sformułowanie zbrodni przeciwko ludzkości zawierało różnice — nie tylko redakcyjne, lecz także polegające na wykreśleniu klauzuli „przy popełnianiu jakiejkolwiek zbrodni wchodzącej w zakres kompetencji Trybunału lub w związku z nią"19. Szerokie określenie tych zbrodni łącznie ze zbrodnią ludobójstwa zawarto też $\mathrm{w}$ konwencji o niestosowaniu przedawnienia wobec zbrodni wojennych i zbrodni przeciw ludzkości ${ }^{20}$.

Z kolei statuty trybunałów karnomiędzynarodowych utworzonych przez Radę Bezpieczeństwa zawierają mało precyzyjne i często sprzeczne $\mathrm{z}$ sobą postanowienia definiujące te zbrodnie ${ }^{21}$. Artykuł 5 statutu Międzynarodowego Trybunału Karnego dla byłej Jugosławii ${ }^{22}$ wymieniał ich przykłady, wymagając, by zbrodnie te były popełnione w czasie konfliktu zbrojnego (niezależnie od tego, czy konflikt ma charakter międzynarodowy, czy wewnętrzny) oraz by były skierowane przeciwko ludności cywilnej. Z kolei art. 3 statutu Międzynarodowego Trybunału Karnego dla Ruandy ${ }^{23}$, powtarzając katalog czynów, wymagał, by były one popełnione jako część szeroko zakrojonego lub systematycznego ataku przeciwko ludności cywilnej ze względów narodowościowych, politycznych, etnicznych, rasowych lub religijnych.

Natomiast delegacje negocjujące statut stałego MTK zgodziły się, że zbrodnie przeciwko ludzkości są karalne na podstawie międzynarodowego prawa zwyczajowego, ale też że dotychczasowe precedensy nie składają się na spójne rozumienie tego zagadnienia ${ }^{24}$. Pomimo istniejących „płynności” ${ }^{25}$ definicyjnych sytuacja się zmieniła także pod kątem metody ustalania tej definicji — negocjo-

18 Zob. A. Basak, International custom and the experience of Nuremberg, [w:] Essays in Memory of Professor Karol Wolfke, red. B. Krzan (,Wroclaw Review of Law, Administration \& Economics" 8, 2018, nr 2), s. 263.

19 Zob. T. Cyprian, J. Sawicki, op. cit., s. 434 n.

20 Przyjętej przez Zgromadzenie Ogólne Organizacji Narodów Zjednoczonych dnia 26 listopada 1968 roku (Dz.U. z 1970 r. Nr 26, poz. 208).

${ }^{21}$ H. von Hebel, D. Robinson, Crimes within the jurisdiction of the Court, [w:] The International Criminal Court: The Making of the Rome Statute: Issues, Negotiations, Results, red. R.S. Lee, The Hague 1999, s. 90; L.N. Sadat, A new global treaty on crimes against humanity future prospects, [w:] Arcs of Global Justice: Essays in Honour of William A. Schabas, red. M.M. deGuzman, D.M. Amann, Oxford 2018, s. 382.

22 UN Doc. S/RES/827 (1993), annex.

23 UN Doc. S/RES/955 (1994), annex.

24 D. Robinson, Defining “crimes against humanity” at the Rome conference, „American Journal of International Law" 93, 1999, s. 43.

25 J. Doria, Whether crimes against humanity are backdoor war crimes, [w:] The Legal Regime of the ICC: Essays in Honour of Prof. I.P. Blishchenko, red. J. Doria et al., Leiden-Boston 2009, s. 645. 
wanej, a nie narzucanej przez sprawiedliwość zwycięzców (MTW) albo jednostronnie przez Radę Bezpieczeństwa ${ }^{26}$. Na konferencji rzymskiej postanowiono tym samym o wypracowaniu odrębnej definicji zamiast inkorporowania już istniejących ${ }^{27}$. Nie chodziło bynajmniej o stworzenie rewolucyjnego, nowatorskiego rozwiązania, ale raczej o kompilację wypracowanych przez wcześniejsze trybunały (ad hoc) rozwiązań, odzwierciedlających stan norm zwyczajowych ${ }^{28}$.

Statut rzymski definiuje zbrodnie jako:

którykolwiek z następujących czynów, popełniony w ramach rozległego lub systematycznego, świadomego ataku skierowanego przeciwko ludności cywilnej: (a) zabójstwo; (b) eksterminacja; (c) niewolnictwo; (d) deportacja lub przymusowe przemieszczanie ludności; (e) uwięzienie lub inne dotkliwe pozbawienie wolności fizycznej z naruszeniem podstawowych reguł prawa międzynarodowego; (f) tortury; (g) zgwałcenie, niewolnictwo seksualne, przymusowa prostytucja, wymuszona ciąża, przymusowa sterylizacja oraz jakiekolwiek inne formy przemocy seksualnej porównywalnej wagi; (h) prześladowanie jakiejkolwiek możliwej do zidentyfikowania grupy lub zbiorowości z powodów politycznych, rasowych, narodowych, etnicznych, kulturowych, religijnych, płci [...] lub z innych powodów powszechnie uznanych za niedopuszczalne na podstawie prawa międzynarodowego, w związku z jakimkolwiek czynem, do którego odnosi się niniejszy ustęp, lub z jakąkolwiek zbrodnią objętą jurysdykcją Trybunału; (i) wymuszone zaginięcia osób; (j) zbrodnia apartheidu; (k) inne nieludzkie czyny o podobnym charakterze celowo powodujące ogromne cierpienie lub poważne uszkodzenie ciała albo zdrowia psychicznego lub fizycznego ${ }^{29}$.

Tym samym definicja statutowa wykazuje podobieństwo do wcześniejszych regulacji, choć wprowadzono też kilka odstępstw, jak chociażby brak odniesienia do konfliktu zbrojnego, na podobieństwo sformułowania zawartego w statucie trybunału ruandyjskiego, lub wprowadzenie wymogu, by ,atak skierowany przeciwko ludności cywilnej” został „podjęty stosownie do lub dla wsparcia polityki państwowej lub organizacyjnej zakładającej dokonanie takiego ataku"30. Warto w tym kontekście zauważyć, że zrywa się w ten sposób z podejściem wypracowanym przez trybunały utworzone przez Radę Bezpieczeństwa, które wyraźnie odrzuciły ten wymóg na gruncie prawa zwyczajowego ${ }^{31}$.

26 D. Robinson, op. cit., s. 43.

27 M. Płachta, op. cit., s. 381.

28 W szczególności uwzględnienia wymagały następujące kwestie: szczególna postać strony podmiotowej, kwestia istnienia konfliktu zbrojnego, wystąpienie ataku mającego szeroko zakrojony lub systematyczny charakter, kwalifikacja podmiotowa potencjalnych ofiar sprawcy zbrodni przeciwko ludzkości jako cywilów lub ludności w przeważającej mierze cywilnej oraz realizacja planu lub polityki państwowej lub organizacyjnej — zob. T. Iwanek, Zbrodnia ludobójstwa i zbrodnie przeciwko ludzkości w prawie międzynarodowym, Warszawa 2015, s. 193.

${ }^{29}$ AQrt. 7(1). Kolejne ustępy powołanego przepisu szczegółowo definiują te zbrodnie.

30 Art. 7(2)(a) statutu rzymskiego. Por. G. Mettraux, The definition of crimes against humanity and the question of a "policy" element, [w:] Forging a Convention for Crimes Against Humanity, red. L.N. Sadat, Cambridge 2011, s. 279 n.

31 ICTY, Prosecutor v Kunarac, Case Nos. IT-96-23 \& IT-96-23/1-A, § 98 (12.06.2002). 
Kodyfikację zbrodni przeciwko ludzkości w statucie rzymskim uznaje się za konieczną, ale niewystarczającą ${ }^{32}$. Jak zresztą stanowi artykuł 10, ,żadne z postanowień niniejszej części nie może być interpretowane jako ograniczające lub naruszające w jakikolwiek sposób istniejące i rozwijające się zasady prawa międzynarodowego dla celów innych niż niniejszy statut". W ten sposób unika się paraliżu rozwijania międzynarodowego prawa karnego przez kodyfikację dokonaną statutem rzymskim ${ }^{33}$. Należy zauważyć, że przyjęty w 2002 roku statut Trybunału Specjalnego dla Sierra Leone zawiera w art. 2 definicję zbrodni przeciwko ludzkości, która nie powtarza ujęcia ani statutów trybunałów ad hoc, ani statutu MTK.

Na podstawie dotychczasowych rozważań można zatem przyjąć, że rdzeń definicji zbrodni przeciwko ludzkości jest dobrze zakotwiczony w międzynarodowym prawie zwyczajowym, nawet jeśli brakuje zgody co do szczegółowych kwestii ${ }^{34}$. Regulacja jest rozczłonkowana - wystarczy zauważyć, że oddzielnych regulacji traktatowych doczekały się szczegółowe refleksy zbrodni przeciwko ludzkości, jak apartheid ${ }^{35}$, tortury ${ }^{36}$ czy wymuszone zaginięcia ${ }^{37}$.

Pamiętajmy jednak, że to nie tylko kwestia definicji, która wymaga ustalenia. Podejmowane w ramach KPM rozważania równie dobrze mogą przysłużyć się pracom nad stworzeniem bardziej ogólnej konwencji poświęconej zbrodniom międzynarodowym albo też uaktualnieniu konwencji o ludobójstwie ${ }^{38}$.

\section{Prace Komisji Prawa Międzynarodowego}

Dobór tematów rozważanych przez KPM zmienia się w ciągu lat ${ }^{39}$. Zbrodnie przeciwko ludzkości jako zagadnienie nie są na pewno „wielkim tematem

32 L.N. Sadat, A new global treaty..., s. 385.

${ }^{33}$ H. van der Wilt, State practice as element of customary international law: A white knight in international criminal law?, „International Criminal Law Review” 20, 2020, s. 785.

34 Y. Dinstein, Crimes against humanity, [w:] Theory of International Law at the Threshold of the 21st Century: Essays in Honour of Krzysztof Skubiszewski, red. J. Makarczyk, The Hague 1996, s. 896.

35 Międzynarodowa konwencja o zwalczaniu i karaniu zbrodni apartheidu, przyjęta dnia 30 listopada 1973 roku rezolucją 3068 (XXVIII) Zgromadzenia Ogólnego Narodów Zjednoczonych (Dz.U. z 1976 r. Nr 32, poz. 186).

${ }^{36}$ Konwencja w sprawie zakazu stosowania tortur oraz innego okrutnego, nieludzkiego lub poniżającego traktowania albo karania, przyjęta przez Zgromadzenie Ogólne Narodów Zjednoczonych dnia 10 grudnia 1984 roku (Dz.U. z 1989 r. Nr 63, poz. 378).

37 Przyjęta przez Polskę, choć jeszcze nieratyfikowana konwencja - International Convention for the Protection of All Persons from Enforced Disappearance, New York 20.12.2006, „United Nations Treaty Series" 2716, s. 3.

38 C. Kreß, S. Garibian, Laying the foundations for a convention on crimes against humanity: Concluding observations, „Journal of International Criminal Justice” 16, 2018, s. 956.

$39 \mathrm{G}$. Hafner, Is the topic of responsibility of international organizations ripe for codification? Some critical remarks, [w:] From Bilateralism to Community Interest: Essays in Honour of Bruno 
kodyfikacyjnym" w rodzaju (czy na podobieństwo) prawa traktatów albo też prawa odpowiedzialności międzynarodowej, a raczej doskonałym przykładem średniego rodzaju ${ }^{40}$. Zdaje się on niemniej spełniać wszystkie kryteria przyjęte przez Komisję, aby umieścić dany temat w porządku prac: odzwierciedla potrzeby państw w odniesieniu do postępowego rozwoju i kodyfikacji prawa międzynarodowego, istnieje wystarczająca odnośna praktyka państw, a sam jest wystarczająco konkretny i wykonalny ${ }^{41}$. Jeśli przyjmiemy za francuskimi internacjonistami rozróżnienie między zwyczajem tradycyjnym a nowym, tworzonym przez instytucje międzynarodowe, to projekt dotyczący karania i zapobiegania zbrodniom przeciwko ludzkości niewątpliwie wpisuje się w tę drugą kategorię ${ }^{42}$, ale trudno uznać ją bez zastrzeżeń za „dziką" kodyfikację ${ }^{43}$.

Wcześniejsze działania KPM odnosiły się w pierwszej kolejności do zasad norymberskich ${ }^{44}$. Ostatecznie przyjęte „Zasady prawa międzynarodowego uznane w Statucie Trybunału Norymberskiego i w wyroku Trybunału", sformułowane przez Komisję Prawa Międzynarodowego w 1950 roku na podstawie rezolucji 177(II) Zgromadzenia Ogólnego Narodów Zjednoczonych ${ }^{45}$, wywołały skrajnie

Simma, red. U. Fastenrath et al., Oxford 2011, s. 698; por. Ch. Tomuschat, L'exemple de la Commission du droit international, [w:] SFDI, Colloque d'Aix-en-Provence, La codification du droit international, Paris 1993, s. 179.

40 Por. G. Nolte, The International Law Commission facing the second decade of the twentyfirst century, [w:] From Bilateralism to Community Interest..., s. 783.

${ }^{41}$ Report of the International Law Commission on the work of its forty-ninth session, 12.0518.07.1997, UN Doc A/52/10 (1997), „Yearbook of the International Law Commission” II (2), 1997, § 238, s. 72. Dodano przy tym, że ,in the selection of new topics, the Commission should not restrict itself to traditional topics, but could also consider those that reflect new developments in international law and pressing concerns of the international community as a whole".

${ }^{42}$ Zob. G. Abi-Saab, La Commission du droit international, la codification et le processus de formation de droit international, [w:] Making Better International Law: Proceedings of the United Nations Colloquium on Progressive Development and Codification of International Law, New York 1998, s. 195 n.

43 P.M. Dupuy, Coutume sage et coutume sauvage, [w:] Mélanges offerts à Charles Rousseau: La communauté international, Paris 1974, s. 75.

44 Zasady norymberskie sformułowane w statucie Międzynarodowego Trybunału Wojskowego zostały następnie zatwierdzone rezolucją Zgromadzenia Ogólnego ONZ nr 3(I) z 13 lutego 1946 oraz nr 95(I) z 11 grudnia 1946 roku. W obu przypadkach nie pojawiło się bezpośrednie ani konkretne nawiązanie do kategorii zbrodni. W drugiej z przywołanych rezolucji znalazło się jednak wezwanie do Komitetu ds. kodyfikacji prawa międzynarodowego (nim jeszcze została formalnie utworzona Komisja Prawa Międzynarodowego) do sformułowania zasad norymberskich.

45 Potwierdzonych przez Zgromadzenie Ogólne jako „morderstwa, wytępianie, obracanie ludzi w niewolników, deportacja i inne czyny nieludzkie, których dopuszczono się przeciwko jakiejkolwiek ludności cywilnej, przed wojną lub podczas niej, albo prześladowania ze względów politycznych, rasowych lub religijnych przy popełnianiu jakiejkolwiek zbrodni wchodzącej w zakres kompetencji Trybunału lub w związku z nią, niezależnie od tego, czy było to zgodne, czy też stało w sprzeczności z prawem kraju, w którym zbrodni dokonano" (zasada VI). 
rozbieżne oceny — od zaciętej jej obrony ${ }^{46}$ aż po kategoryczne sądy, że była błędna ${ }^{47}$.

Ponownie kwestia zdefiniowania zbrodni przeciw ludzkości wypłynęła w związku z pracami nad projektem kodeksu zbrodni przeciwko pokojowi i bezpieczeństwu ludzkości (Kodeksu Zbrodni Międzynarodowych). Nad tym projektem Komisja Prawa Międzynarodowego pracowała w okresie 1949-1954, a następnie w latach 1982-1996. Przy drugim podejściu specjalny sprawozdawca D. Thiam zwracał uwagę, by „przyznać zbrodniom przeciwko ludzkości należne im miejsce”48. Warto zauważyć, że przyjęta w 1991 roku wersja projektu kodeksu zupełnie zrezygnowała z tego terminu, zastępując go „systematycznymi lub masowymi naruszeniami praw człowieka”. Ostateczny projekt, z 1996 roku, powrócił jednak do używania (i zdefiniowania) zbrodni przeciwko ludzkości ${ }^{49}$.

Podczas 64. sesji Komisji w 2012 roku jeden z jej członków, prof. Sean D. Murphy, zaproponował jako kolejny temat prac zbrodnie przeciwko ludzkości. Przygotował on dość obszerny materiał wstępny ${ }^{50}$, w którym wskazywał, że powszechna konwencja odnosząca się do zbrodni przeciwko ludzkości jest kluczowym brakującym ogniwem $w$ istniejących ramach międzynarodowego prawa humanitarnego, międzynarodowego prawa karnego oraz międzynarodowego prawa praw człowieka ${ }^{51}$.

Po dłuższej dyskusji Komisja umieściła ten temat w programie swych prac. Kontrowersje związane z pewnymi zagadnieniami dobitnie obrazują obrady w ramach VI Komitetu Zgromadzenia Ogólnego ONZ ${ }^{52}$. Jeszcze w 2013 roku mocno krytyczne stanowisko wyrazili przedstawiciele Francji ${ }^{53}$ i Iranu ${ }^{54}$. Z kolei Malezja argumentowała, że jest jeszcze za wcześnie na wypracowanie konwencji

46 T. Cyprian, J. Sawicki, Walka o zasady norymberskie 1945-1955, Warszawa 1956.

47 R.R. Baxter, The effects of ill-conceived codification and development of international law, [w:] Recueil d'études de droit international en hommage à Paul Guggenheim, Genève 1968, s. 148.

48 D. Thiam, Seventh report on the draft Code of Crimes against the Peace and Security of Mankind, „Yearbook of the International Law Commission” II(1), 1989, s. 86 (§ 31 i 39).

49 Draft Code of Crimes against the Peace and Security of Mankind art. 18, in Report of the International Law Commission on the work of its forty-eighth session, U.N. GAOR, 51st Sess., Supp. No. 10, U.N. Doc. A/51/10 (1996), art. 18: „A crime against humanity means any of the following acts, when committed in a systematic manner or on a large scale and instigated or directed by a Government or by any organization or group".

50 Report of the International Law Commission Sixty-fifth session (6.05-7.06 and 8.079.08.2013). General Assembly. Official Records. Sixty-eighth session. Supplement No. 10 (A/68/10) A/68/10, Annex B: Crimes against humanity (Mr. Sean D. Murphy), s. $140 \mathrm{n}$.

51 Ibidem, $\S 3$.

52 Zob. First report on crimes against humanity, by Sean D. Murphy, Special Rapporteur, UN Doc. A/CN.4/680, s. 8 n.

53 Zob. https://papersmart.unmeetings.org/media2/703468/france-e.pdf (dostęp: 30.12.2019).

54 Statement by Professor Djamchid Momtaz, 68th Session of the General Assembly, 6th Committee, under agenda item 81 (5.11.2013) s. 7, https://papersmart.unmeetings.org/media2/1156427/ iran.pdf (dostęp: 30.12.2019). 
dotyczącej zbrodni przeciwko ludzkości ${ }^{55}$. Brak poparcia zgłaszany był także między innymi przez przedstawiciela Holandii, który wskazywał, że brakującym ogniwem jest nie brak definicji zbrodni przeciwko ludzkości, a raczej międzynarodowego instrumentu dotyczącego wzajemnej pomocy prawnej odnoszącego się do wszystkich głównych zbrodni międzynarodowych, łącznie ze zbrodniami przeciwko ludzkości ${ }^{56}$. Takie szersze ujęcie pozwoliłoby na uwzględnienie postępu dokonanego w ciągu kilku dekad, jakie upłynęły od czasu uchwalenia konwencji o ludobójstwie i konwencji genewskich. Podnoszono już wcześniej, że prowadzone prace kodyfikacyjne nie powinny podważać ustaleń dokonanych na konferencji rzymskiej. Co ciekawe, argument bezzsadności prac ze względu na stały MTK zgłaszany był przez państwa, które nigdy nie ratyfikowały statutu rzymskiego, otwarcie krytykując tę formę realizacji międzynarodowej sprawiedliwości karnej ${ }^{57}$.

Powołany na specjalnego sprawozdawcę S.D. Murphy przygotował łącznie cztery raporty, które stały się podstawą prac Komisji i komentarzy ze strony państw oraz organizacji międzynarodowych. Ostatecznie 22 maja 2019 roku przyjęto w drugim czytaniu projekt artykułów, a następnie w sesji letniej tekst komentarzy. Równocześnie, zgodnie z art. 23 swojego statutu, KPM przekazała Zgromadzeniu Ogólnemu projekt artykułów dotyczących zapobiegania i karania zbrodni przeciwko ludzkości, zalecając opracowanie konwencji przez Zgromadzenie Ogólne albo na konferencji międzyrządowej na podstawie projektu artykułów.

Jak zauważono w komentarzach dołączonych do przyjętego w drugim czytaniu projektu, celem artykułów nie miała być jedynie kodyfikacja dotychczas obowiązującego prawa zwyczajowego, lecz przygotowanie regulacji opartych na uznawanych rozwiązaniach, które byłyby skuteczne i możliwe do zaakceptowania przez państwa ${ }^{58}$.

Ponadto w komentarzu stwierdzono, że projekt artykułów unika konfliktów z zobowiązaniami państw wynikającymi z aktów ustanawiających trybunały międzynarodowe, zarówno stały MTK, jak i trybunały hybrydowe o mieszanej,

55 Zob. https://papersmart.unmeetings.org/media2/703723/malaysia-rev.pdf oraz stanowisko wyrażone podczas sesji w 2014 roku: http://statements.unmeetings.org/media2/4655090/malaysia-color.pdf (dostęp: 30.12.2019).

56 https://papersmart.unmeetings.org/media2/703600/netherlands.pdf (dostęp: 30.12.2019). Zob. też D. Tladi, Complementarity and cooperation in international criminal justice: Assessing initiatives to fill the impunity gap, ISS Paper 277, 2014, s. 7. Zob. też International cooperation in the fight against the crime of genocide, crimes against humanity and war crimes, draft resolution, (28 March 2013) UN Doc E/CN.15/2013/L.5.

57 Zob. np. stanowisko Federacji Rosyjskiej, a także wyrażone w trakcie kolejnych sesji (2015) stanowisko Chin: http://statements.unmeetings.org/media2/7654986/china-english-.pdf oraz Iranu: http://statements.unmeetings.org/media2/7655056/iran.pdf i wreszcie podniesioną dopiero w 2016 roku krytykę Indii: http://statements.unmeetings.org/media2/7663517/india.pdf (dostęp: 30.12.2019).

58 ILC Report, A/74/10, 2019, s. 23, § 3. 
międzynarodowo-krajowej jurysdykcji i składzie. Podkreślono przy tym odrębne przedmioty regulacji: podczas gdy statut rzymski reguluje stosunki w relacji pionowej (pomiędzy MTK a stronami statutu), projekt artykułów skupia się na przyjęciu regulacji krajowych oraz na współpracy międzypaństwowej, także w odniesieniu do zapobiegania. Zwrócono uwagę, że projekt artykułów przyczynia się do implementacji zasady komplementarności wynikającej ze statutu rzymskiego. Centralnym zamysłem kodyfikacji było przede wszystkim podbudowanie prawodawstwa wewnętrznego i odnośnej działalności sądów krajowych oraz ustanowienie ram współpracy w zakresie ekstradycji oraz pomocy prawnej ${ }^{59}$.

Zawarta w art. 2 definicja zbrodni przeciwko ludzkości powtarza analogiczną treść ujętą $\mathrm{w}$ art. 7 statutu rzymskiego. Takie mechaniczne powtórzenie może wywołać krytykę, gdyż utracono w ten sposób możliwość postępu ${ }^{60}$. W porównaniu z pierwowzorem wprowadzono jedynie trzy modyfikacje. Dwie pierwsze mają charakter wybitnie techniczny ${ }^{61}$, natomiast ostatnia ze zmian polega na nieuwzględnieniu w projekcie KPM pojęcia „płeć” (gender), zawartej w art. 7(3) statutu rzymskiego ${ }^{62}$.

W ust. 3 art. 2 projektu zaznaczono, że przyjęta definicja nie stanowi przeszkody dla jakiejkolwiek szerszej, wynikającej czy to z międzynarodowego instrumentu, międzynarodowego prawa zwyczajowego, czy z prawa krajowego. W ten sposób łączy się kompleksowe spojrzenie, zaproponowane przez Komisję, z możliwością dalszego rozwoju. Dzięki rozważaniom zawartym w komentarzu, a także wcześniejszym dyskusjom w obrębie Komisji i raportom specjalnego sprawozdawcy, następuje ugruntowanie pojęcia, choć same komentarze zdają się budować wrażenie większej klarowności definicyjnej aniżeli rzeczywiście istniejąca ${ }^{63}$.

Projekt artykułów ustanawia główne zobowiązania po stronie państw: nieangażowania się w czyny stanowiące zbrodnie przeciwko ludzkości, a także zapobiegania im oraz ich karania. Dodatkowo podkreślono kategoryczny zakaz usprawiedliwiania popełnienia tych zbrodni, nawet poprzez odwołanie do jakichkolwiek nadzwyczajnych okoliczności. Ten ostatni zakaz pierwotnie zawarto jako element

59 S.D. Murphy, Foreword, „Journal of International Criminal Justice” 16, 2018, s. 679.

60 C. Kreß, S. Garibian, op. cit., s. 913.

61 Polegają na zastąpieniu sformułowania „dla celów niniejszego Statutu” sformułowaniem „dla celów niniejszego projektu artykułów” oraz na niepowtarzaniu formuły z art. 7(1)(h) statutu, która odnosiła się do prześladowania „w związku [...] z jakąkolwiek zbrodnią objętą jurysdykcją Trybunału", a która została wykreślona jako mająca wyłącznie sens w odniesieniu do definiowania jurysdykcji przedmiotowej MTK.

62 W komentarzu uzasadniono taki krok możliwością uwzględniania zmieniającego się znaczenia tego terminu; UN Doc. A/74/10, s. 45 n. (§ 41-42).

63 C. Kreß, S. Garibian, op. cit., s. 917. Autorzy zwracają uwagę na rozbudowane, choć nie do końca głębokie rozważania definicyjne zawarte w raportach specjalnego sprawozdawcy (ibidem, s. 916, przyp. 29). 
zobowiązania do zapobiegania ${ }^{64}$. Odnośną zmianę, polegającą na rozbudowaniu zobowiązania i uczynieniu go bardziej precyzyjnym, należy przyjąć z uznaniem.

W projekcie brakuje bardziej bezpośredniego nawiązania do odpowiedzialności państwa za zbrodnie przeciwko ludzkości65. Można to usprawiedliwiać jego oczywistością, chociażby w świetle orzeczenia MTS w sprawie Bośni ${ }^{66}$, ale $\mathrm{w}$ warstwie symbolicznej rodzi on niedosyt, nawet jeśli powtarza praktykę zastosowaną przy formułowaniu konwencji o ludobójstwie ${ }^{67}$.

Zobowiązanie do zapobiegania zdefiniowano $\mathrm{w}$ art. 4 projektu artykułów, w którym wymieniono dostępne sposoby ${ }^{68}$ : skuteczne środki prawodawcze, administracyjne, sądowe lub inne stosowne metody na każdym terytorium podlegającym jurysdykcji danego państwa oraz przez współpracę z innymi państwami, właściwymi organizacjami międzyrządowymi i - gdy to stosowne - innymi organizacjami.

Projekt artykułów KPM wyklucza wydalanie osoby do innego państwa, jeśli miałoby to oznaczać zagrożenie takiej osoby zbrodniami przeciwko ludzkości (non refoulement ${ }^{69}$. Rozbudowany art. 6 poświęcono kryminalizacji na gruncie prawa krajowego, zobowiązując każde państwo do penalizacji nie tylko bezpośredniego sprawstwa, lecz także usiłowania oraz sprawczych i niesprawczych postaci zjawiskowych (podżegania oraz pomocnictwa). W tym zakresie należy zauważyć daleko idącą zbieżność z postanowieniami statutu rzymskiego ${ }^{70}$. Nie ujęto natomiast kryminalizacji przygotowania. Państwa mają zobowiązać się do podjęcia w prawie wewnętrznym środków zmierzających do wykluczenia przedawnienia wymienionych przestępstw, a także do zapewnienia im odpowiednich, właściwych kar, uwzględniających ich poważny charakter ${ }^{71}$.

64 Text of the draft articles on crimes against humanity adopted by the Commission on first reading, A/72/10, 2017, s. 12 (art. 4). Przy okazji wypada zauważyć, że przyjęty w pierwszym czytaniu projekt KPM posługiwał się jednym ogólnym zobowiązaniem zapobiegania i karania (art. 2 $[2])$.

65 C. Kreß, S. Garibian, op. cit., s. 919.

${ }^{66}$ Application of the Convention on the Prevention and Punishment of the Crime of Genocide (Bosnia-Herzegovina v Serbia \& Montenegro), 26.02.2007, ICJ Rep. 2007, s. 219-220 (§ 427) (,, [t] he obligation on each contracting State to prevent genocide is both normative and compelling. It is not merged in the duty to punish, nor can it be regarded as simply a component of that duty'). Zob. też W.A. Schabas, Prevention of crimes against humanity, „Journal of International Criminal Justice” 16, 2018, s. 705.

${ }^{67}$ C. Kreß, S. Garibian, op. cit., s. 920.

$68 \mathrm{~W}$ przeciwieństwie do projektu przyjętego w pierwszym czytaniu nie jest to jedynie wyliczenie przykładowe. Zob. UN Doc. A/72/10, s. 12 zawierający sformułowanie „między innymi przez".

69 Draft article 5 (1). Zgodnie z ust. 2 w ocenie, czy istnieją poważne podstawy do uznania takiego zagrożenia, uwzględnia się wszystkie okoliczności.

70 Art. 6(3) można zestawić $z$ art. 28 statutu, art. 6(4) - z art. 33, a art. 6(5) - z art. 27(1) statutu rzymskiego.

71 Odpowiednio ust. 6 i 7 art. 6. 
$\mathrm{Z}$ zastrzeżeniem odmiennej regulacji krajowej w art. 6 przewidziano też ustanowienie, o ile to stosowne, odpowiedzialności osób prawnych ${ }^{72}$. Naturalnie łączy się odpowiedzialność karnomiędzynarodową z osobą fizyczną, choć nie można zapominać o dorobku Norymbergi odnośnie do osób prawnych ${ }^{73}$. Takiej modalności, wzorowanej na protokole fakultatywnym z 2000 roku do konwencji o prawach dziecka w sprawie handlu dziećmi, dziecięcej prostytucji i dziecięcej pornografii, nie wykluczono przecież również w protokole z Malabo, przyjętym w 2014 roku, a który zmierza do rozszerzenia jurysdykcji Afrykańskiego Trybunału Sprawiedliwości i Praw Człowieka oraz Ludów ${ }^{74}$.

Duży nacisk położony został na zbudowanie podstaw wykonywania jurysdykcji krajowej. Projekt odnosi się nie tylko do łączników terytorialnego i personalnego - zarówno czynnego (przez odwołanie do obywatelstwa sprawcy albo jego zamieszkania na terytorium, gdy jest on/ona bezpaństwowcem), jak i biernego (gdy pokrzywdzony jest obywatelem danego państwa lub gdy uzna ono to za stosowne). W myśl art. 7(2) państwa podejmą także środki konieczne do utworzenia jurysdykcji dla forum deprehensionis, to jest według miejsca ujęcia podejrzanego. Przyjęte rozwiązania nie wykluczają wykonywania innej jurysdykcji karnej, zgodnie z prawem krajowym. Wracając do państwa miejsca ujęcia, należy podkreślić, że ma ono - o ile nie przekazało domniemanego sprawcy innemu państwu lub wydało kompetentnemu trybunałowi karnomiędzynarodowemu - obowiązek przekazania sprawy swoim organom ścigania, co ucieleśnia tradycyjną zasadę aut dedere aut iudicare. Ekstradycji poświęcono zresztą osobny przepis w projekcie, który ogólnie zmierza do ułatwienia przekazywania osób między państwami ${ }^{75}$. Rozbudowanej regulacji doczekała się też współpraca między państwami w zakresie śledzenia, ścigania i karania tego przestępstwa, łącznie z wzajemną pomocą prawną, ujętą dodatkowo w załączniku.

W tym kontekście należy zwrócić uwagę na nieistnienie bezpośredniego odniesienia do bardzo kontrowersyjnej kwestii amnestii ${ }^{76}$. Jedynie w komentarzach zawarto liczne, choć mgliste, odniesienia do tej kwestii, należącej niewątpliwie do najtrudniejszych zagadnień. Reprezentowane są skrajnie przeciwne stanowiska — od postulatów ujęcia wprost całkowitego zakazu amnestii ${ }^{77}$, poprzez

72 Może ona przyjąć formę odpowiedzialności karnej, cywilnej lub administracyjnej.

73 Por. J.A. Bush, The prehistory of corporations and conspiracy in international criminal law: What Nuremberg really said, „Columbia Law Review” 109, 2009, s. 1094 n.

74 Zob. $\$ 45$ komentarza do art. 6, UN Doc. A/74/10, s. 82.

75 Zob. art. 13 projektu, który odzwierciedla niekiedy dość życzeniową, mało praktyczną postawę. Trudno bowiem spodziewać się zbytniego przywiązania do rezygnacji z tajemnicy bankowej (art. 14[4]) albo bezwnioskowego udzielania informacji (art. 14[6]).

76 Zob. np. K. Holy, Prawo międzynarodowe publiczne wobec amnestii, Warszawa 2015.

77 Zob. H.A. Relva, Three propositions for a future convention on crimes against humanity: The prohibition of amnesties, military courts, and reservations, „Journal of International Criminal Justice" 16, 2018, s. 857 n. 
propozycje uwzględnienia tego środka ${ }^{78}$. $\mathrm{Z}$ tego względu mało prawdopodobne było wypracowanie wspólnego podejścia, dlatego zgodnie z wcześniejszymi przewidywaniami ${ }^{79}$ zdecydowano się na pominięcie tego zagadnienia $\mathrm{w}$ wypracowanym ostatecznie tekście kodyfikacji.

Nie ma w projekcie odniesienia do kwestii dopuszczalności ewentualnych zastrzeżeń, zawarto w nim za to odrębny art. 15, poświęcony rozstrzyganiu sporów. Zobowiązuje on państwa do starań, by rozwiązywać spory dotyczące interpretacji i stosowania artykułów w drodze negocjacji. Dziwnie brzmi ust. 2 powołanego przepisu, wymagając, by na żądanie jednej ze stron sporu został on przekazany Międzynarodowemu Trybunałowi Sprawiedliwości, o ile nie zdecydowano się na drogę arbitrażu. Dodatkowe osłabienie tej klauzuli przynosi kolejny ustęp, dający możliwość wyłączenia (opt out). W porównaniu z art. IX konwencji o ludobójstwie następuje znaczące rozmycie klauzuli kompromisowej, co wykluczy uruchomienie MTS jako decydującego forum.

\section{Potrzeba i znaczenie odrębnej regulacji traktatowej}

Działania Komisji zdają się dopełniać prace nad częścią materialną międzynarodowego prawa karnego. $\mathrm{W}$ odniesieniu do braku samodzielnej konwencji regulującej zbrodnie przeciwko ludzkości już wcześniej zauważono, że ta luka jest akceptowana z szokującym samozadowoleniem politycznych decydentów ${ }^{80}$. Specjalna inicjatywa w tym zakresie została w 2008 roku podjęta na Uniwersytecie Waszyngtońskim. Zaowocowała ona przedstawieniem projektu międzynarodowej konwencji dotyczącej zapobiegania i karania zbrodni przeciwko ludzkości $^{81}$. Była ona katalizatorem podjęcia prac w ramach KPM.

Nieistnienie normy traktatowej nie jest bezwzględną przeszkodą $\mathrm{w}$ pociągnięciu do odpowiedzialności na gruncie prawa międzynarodowego. Podstaw do tego może przecież dostarczać międzynarodowe prawo zwyczajowe ${ }^{82}$.

78 Zob. konkretną propozycję treści artykułu - S.M.H. Nouwen, Is there something missing in the proposed convention on crimes against humanity? A political question for states and a doctrinal one forInternational Law Commission, „Journal of International Criminal Justice” 16, 2018, s. 908.

79 D. Orentlicher, Immunities and amnesties, [w:] Forging a Convention for Crimes Against Humanity, red. L.N. Sadat, Cambridge 2013, s. 222.

80 M.Ch. Bassiouni, Crimes against humanity: The need for a specialized convention, „Columbia Journal of Transnational Law" 31, 1994, s. 457.

${ }^{81}$ L.N. Sadat, A comprehensive history of the proposed international convention on the prevention and punishment of crimes against humanity', [w:] Forging a Convention..., s. 323 n.

82 W. Czapliński, Customary international law as a basis of an individual criminal responsibility, [w:] Prosecuting International Crimes: A Multidisciplinary Approach, red. B. Krzan, Leiden-Boston 2016, s. 53 n.; K. Ambos, Treatise on International Criminal Law, t. 2. The Crimes and Sentencing, Oxford 2014, s. 47. 
Oczywiście niewystarczająca precyzja wywołuje wiele problemów, przede wszystkim ze względu na zasadę legalizmu ścigania karnego ${ }^{83}$, wyrażającą liczne postulaty właściwe prawu pisanemu ${ }^{84}$.

Warto przy tym zaznaczyć, że nie mówimy o zwyczaju w znaczeniu tradycyjnym, jako niepisanych normach regulujących stosunki międzypaństwowe, lecz o zbiorze norm stosowanych przede wszystkim przez trybunały karnomiędzynarodowe do rozstrzygnięcia o winie i odpowiedzialności karnej na gruncie prawa międzynarodowego osób fizycznych ${ }^{85}$. Nawiązując wprost do raportu Sekretarza Generalnego ONZ, odnoszącego się do powołania tej instytucji sądowej ${ }^{86}$, bez zbytnich ozdobników Izba Apelacyjna trybunału jugosłowiańskiego wyłożyła jedyny powód, dla którego trybunał miał stosować prawo zwyczajowe — to jest w celu uniknięcia naruszenia zasady nullum crimen sine lege, w razie gdy strona konfliktu nie była związana konkretną umową międzynarodową ${ }^{87}$. Brak praktyki kompensować ma opinio iuris $^{88}$. Następuje zatem odwrócenie tradycyjnej logiki tworzenia prawa zwyczajowego ${ }^{89}$.

Trzeba jednak pamiętać, że ostatecznie poza danym kontekstem instytucjonalnym państwa utrzymują swoją kontrolę nad rozwojem prawa zwyczajowego, co widać doskonale w ograniczonym zaufaniu, jakie pokładali w sędziach twórcy statutu rzymskiego.

Niezależnie od krytyki ${ }^{90}$ obowiązujący państwa zakaz popełniania zbrodni przeciwko ludzkości ${ }^{91}$ można wręcz traktować jako normę peremptoryjną

83 Por. Th. Meron, Customary humanitarian law: From the academy to the courtroom, [w:] idem, The Making of International Criminal Justice. A View from the Bench: Selected Speeches, Oxford 2011, s. 32 n.

${ }^{84}$ Zob. S. Lamb, Nullum crimen, nulla poena sine lege in inernational criminal law, [w:] The Rome Statute of The International Criminal Court: A Commentary, t. 1, red. A. Cassese, P. Gaeta, J.R.W.D. Jones, Oxford 2002, s. 734; oraz B. Krzan, Obowiazywanie zasady nulla poena sine lege z perspektywy międzynarodowych trybunatów karnych, [w:] Prawo międzynarodowe: idee a rzeczywistość, red. E. Cała-Wacinkiewicz, Warszawa 2018, s. 393.

85 Zob. L. van den Herik, The decline of customary international law as a source of international criminal law, [w:] Custom's Future: International Law in a Changing World, red. C. Bradley, Cambridge 2016, s. $231 \mathrm{n}$.

86 UN Doc. S/25704, 3 May 1993, § 34.

87 ICTY, Prosecutor v. D. Tadić, Decision on the Defence Motion for Interlocutory Appeal, 2.10.1995, § 143 .

88 Sztandarowym przykładem może być orzeczenie w sprawie Kupreškicia: ICTY, Trial Chamber, Prosecutor v. Kupreškic, Case No. IT-95-16-T, 14.01.2000, § 527. Zob. też M. Frulli, The contribution of international criminal tribunals to the development of international law: The prominence of opinio juris and the moralization of customary law, „The Law \& Practice of International Courts and Tribunals" 14, 2015, s. 80 n.; oraz krytycznie W. Czapliński, op. cit., s. 58.

89 P.M. Dupuy, op. cit., s. 84; F.L. Bordin, Reflections of customary international law: The authority of codification conventions and ILC draft articles in international law, ICLQ 63, 2014, s. 565.

90 Zob. R. O'Keefe, International Criminal Law, Oxford 2015, s. 81, przywołujący niekonsekwencje w komentarzu KPM do artykułów o odpowiedzialności państw ( $\$ 4$ do art. 26, ale z całkowitym pominięciem tych kwestii w komentarzu do art. 40).

${ }^{91}$ L.N. Sadat, A new global treaty..., s. 380.

Studia nad Autorytaryzmem i Totalitaryzmem 42, nr 2, 2020

(C) for this edition by CNS 
powszechnego prawa międzynarodowego ${ }^{92}$, co zresztą znalazło potwierdzenie w orzecznictwie trybunałów karnomiędzynarodowych ${ }^{93}$. Na podobnym stanowisku stały także sądy niektórych państw ${ }^{94}$. Z perspektywy naszych rozważań trzeba też zauważyć, że takie stanowisko zostało zawarte w preambule projektowanych artykułów.

W nowej konwencji widzi się źródło uniwersalnej definicji zbrodni przeciwko ludzkości, wzmacniającej już istniejące ${ }^{95}$. Nieistnienie traktatowej regulacji zbrodni przeciwko ludzkości rozmywa tę kategorię zbrodni, prowadząc do pomieszania z innymi zbrodniami (przeciwko pokojowi, wojennymi, a nawet ludobójstwa $)^{96}$. Można nie tylko w tym kontekście mówić wręcz o specyficznym rozczarowaniu w sytuacji, gdy okazuje się, że dany czyn nie wypełnia znamion ludobójstwa, umożliwiając uznanie go „zaledwie” za zbrodnię przeciwko ludzkości ${ }^{97}$, a nie za kwalifikowaną, najcięższą postać zbrodni przeciwko ludzkości. Można jednocześnie zauważyć, że nieistnienie odrębnej konwencji odnoszącej się do zbrodni przeciwko ludzkości sprzyja, a nawet często prowadzi do nadużywania konwencji o ludobójstwie ${ }^{98}$. Pamiętamy o „subtelnej”, jak pisał J. Waszczyński ${ }^{99}$, różnicy w stronie podmiotowej (zamiarze) — w wypadku ludobójstwa sprawca działa w zamiarze wytępienia grupy, w wypadku zaś pozostałych zbrodni przeciwko ludzkości sprawca dokonuje swych czynów ze względu na przy-

92 M.Ch. Bassiouni, Crimes Against Humanity: Historical Evolution and Contemporary Application, Cambridge 2011, s. 263-269, 452; Ch. Tams, Enforcing Obligations Erga Omnes in International Law, Cambridge 2005, s. 144-145; R. Dubler, M. Kalyk, Crimes against Humanity in the 21st Century: Law, Practice and Threats to International Peace and Security, Leiden-Boston 2018, s. 640-642. Można jednak zastanawiać się, na ile norma peremptoryjna (w tym przypadku zakaz wiążący państwa) automatycznie przekłada się na tak wzmocnioną normę wiążącą jednostki (osoby fizyczne) — zob. R. O'Keefe, International Criminal..., s. 82.

93 Znakomitym potwierdzeniem takiego podejścia jest orzeczenie Izby Procesowej MTKJ, która w sprawie Kupreskicia uznała, że większość norm międzynarodowego prawa humanitarnego, w szczególności tych zakazujących zbrodni wojennych, zbrodni przeciwko ludzkości i ludobójstwa, jest także niederogowalnymi normami prawa międzynarodowego (ius cogens) - zob. ICTY, The Prosecutor v. Kupreskić et al., Trial Chamber, Judgement, 14.01.2000, IT-95-16-T, § 520.

94 Zob. E. van Sliedregt, Criminalization of crimes against humanity under national law, „Journal of International Criminal Justice” 16, 2018, s. 729-749.

95 G.H. Stanton, Why the world needs an international convention on crimes against humanity, [w:] Forging a Convention for Crimes Against Humanity, red. L.N. Sadat, Cambridge 2011, s. 356.

96 Zob. np. ibidem, s. 381; oraz J. Doria, op. cit., s. 645.

97 L.N. Sadat, A new global treaty..., s. 385.

98 Ibidem. Trudno chociażby uznać prawidłowość kwalifikowania zbrodni popełnionych przez Pol Pota w Kambodży jako samo/auto-ludobójstwa (H. Hannum, International law and Cambodian genocide: The sounds of silence, „Human Rights Quarterly” 11, 1989, s. 82), jako że dokonujący zabójstw, niszczenia przynależeli do tej samej grupy narodowej, etnicznej, rasowej lub religijnej, a ich motywacja była polityczna, ideologiczna oraz klasowa, a zatem brakowało wymaganej przy ludobójstwie kwalifikowanej postaci zamiaru (G. Evans, Crimes against humanity and the responsibility to protect, [w:] Forging a Convention for Crimes..., s. 3).

99 J. Waszczyński, op. cit., s. 71. 
należność ofiary do danej grupy ${ }^{100}$. Innymi słowy można stwierdzić, że podczas gdy ludobójstwo skupia się na zbiorowym charakterze ofiar (pokrzywdzonych), zbrodnie przeciwko ludzkości zmierzają do penalizacji czynów popełnianych zbiorowo $^{101}$. Z kolei należy pamiętać, że dowiedzenie zbrodni przeciwko ludzkości w porównaniu ze zbrodniami wojennymi jest trudniejsze ${ }^{102}$, mimo reprezentowanych niekiedy poglądów traktujących te pierwsze jako niewiele więcej aniżeli zbrodnie wojenne ( $\mathrm{z}$ inną, większą liczbą ofiar) ${ }^{103}$.

Odrębna umowa prowadzić by też mogła do ujednolicenia rozumienia tego pojęcia w poszczególnych krajach, dodatkowo zwiększając nacisk na rządy dopuszczające się tych zbrodni ${ }^{104}$. Takie rozumowanie jest tylko częściowo uzasadnione, miesza bowiem podstawy teorii źródeł prawa międzynarodowego. Nie uwzględnia już istniejącej regulacji zwyczajowej, zakładając, że dopiero konwencja doprowadzi do powstania odnośnej normy iuris cogentis i rozwinięcia w prawo zwyczajowe ${ }^{105}$.

Z najbardziej ogólnej perspektywy trudno byłoby traktować ledwie możliwość ratyfikowania konwencji jako remedium, gdyż wyrażenie ostatecznej zgody na związanie się traktatem nastąpi tylko wtedy, gdy państwo jest tym zainteresowane $^{106}$. Dopiero wówczas można by mówić o „wypełnieniu luki w zakresie odpowiedzialności państwa" 107 . W razie wątpliwości i zastrzeżeń co do zawartości (treści poszczególnych postanowień) umowy zapewne nie zostanie ona ratyfikowana. Naiwnością byłoby zatem sądzić przeciwnie. Można oczywiście próbować formułować domniemanie o wiążącej mocy obowiązującej uzgodnień na konferencji jako prawa zwyczajowego (ex concordia ius oritur) ${ }^{108}$, choć ta-

100 S. Glaser, Droit international pénal conventionnel, Bruxelles 1970, s. 109.

101 C. Stahn, A Critical Introduction to International Criminal Law, Cambridge 2018, s. 52.

Por. J.D. Ohlin, Organizational criminality, [w:] Pluralism in International Criminal Law, red. E. van Sliedregt, S. Vasiliev, Oxford 2014, s. 118.

102 J. Doria, op. cit., s. 660.

103 R.R. Baxter, op. cit., s. 148.

104 G.H. Stanton, op. cit., s. 357.

105 Trudno zgodzić się ze stwierdzeniem Stantona: ,an international convention would increase pressure on governments that commit crimes against humanity because they would be violating international law that will become jus cogens. The convention would develop into customary international law” (ibidem). Jeszcze bardziej kuriozalnie wybrzmiewa stwierdzenie autora: „For crimes against humanity to become customary international criminal law, as the Krstić trial judgment held the crime of genocide has become, they must be defined consistently in an international convention that is ratified by a large majority of the nation States of the world. An international convention would make that possible. Even States that do not wish to submit to the jurisdiction of the International Criminal Court could ratify such a convention, enact national laws against the crimes it defines, and by State practice render it jus cogens" (ibidem, s. 354).

106 Zob. klasyczne, ale nadal aktualne ustalenia sir Cecila Hursta - idem, A plea for the codification of international law on new lines, „Transactions of the Grotius Society” 32, 1946, s. 144.

107 L.N. Sadat, A new global treaty..., s. 385.

108 Por. I. Sinclair, The International Law Commission, Cambridge 1987, s. 124 n. Warto jednak uwzględnić brak ratyfikacji jako negatywną opinio iuris — zob. H. Thirlway, International 
kie stanowisko wydaje się przesadzone, jako że mocno zależy od poziomu akceptacji, wyrażanej przede wszystkim przez ostateczną zgodę na związanie się daną umową międzynarodową. Mniej kontrowersyjne wydają się twierdzenia, że projektowana konwencja w połączeniu ze statutem MTK umożliwiłaby wspólne ramy normatywne i techniczne zaplecze do zapewnienia skuteczności walce ze zbrodniami przeciwko ludzkości oraz odpowiedniej współpracy pomiędzy państwami ${ }^{109}$. Nie ulega wątpliwości, że może także być swoistym „ośrodkiem przejściowym" dla państw, które nie są (jeszcze?) stronami statutu rzymskiego ${ }^{110}$, ale też niekoniecznie potrzebują jakiejkolwiek prawnotraktatowej podstawy do wprowadzenia do wewnętrznego porządku prawnego regulacji zbrodni przeciwko ludzkości. Stosowne kroki można przecież podjąć na podstawie nakazów międzynarodowego prawa zwyczajowego lub jeszcze prościej — w ramach kształtowania warunków jurysdykcji karnej jako emanacji suwerenności.

Wybór metody traktatowej bywa niekiedy uznawany za otwarcie drogi do odwrotnej kodyfikacji przez umożliwienie swego rodzaju „odwrotnej kodyfikacji”, to jest kwestionowania ustaleń dokonanych w konwencji, a przez to osiągnięcie zupełnie odwrotnego skutku ${ }^{111}$. Nawet w przypadku szerokiego poparcia dla danej zasadniczej kwestii może zdarzyć się, że kwestie szczegółowe wywołają kontrowersje ${ }^{112}$. Dlatego nie powinno dziwić podejście specjalnego sprawozdawcy w temacie odpowiedzialności państwa, J. Crawforda, który w ostatnim ze swoich raportów zasugerował odroczenie sformułowania konwencji ${ }^{113}$. Czasami kodyfikacja w formie niewiążącego instrumentu może okazać się tak samo, a nawet bardziej skuteczna aniżeli traktat, który otrzyma ograniczone poparcie ${ }^{114}$.

Trudno więc zaprzeczyć argumentom o przydatności nawet takiej konwencji, która nie weszła w ogóle w życie. Jak słusznie zauważono w kontekście prac nad kodyfikacją międzynarodowej odpowiedzialności państw, w przypadku nieistnienia obowiązujących norm sądy i trybunały międzynarodowe sięgają do jakichkolwiek dostępnych źródeł i właśnie w tym zakresie dorobek Komisji Prawa

Customary Law and Codification: An Examination of the Continuing Role of Custom in the Present Period of Codification of International Law, Leiden 1972, s. 115.

109 G.H. Stanton, op. cit., s. 357.

110 Ibidem.

111 Por. „Yearbook of the International Law Commission” II(2), 2001, s. 24, § 62-63.

112 Zob. uwagi H. Lauterpachta dotyczące kodyfikowania dobrej wiary na gruncie prawa traktatów - idem, Codification and development of international law, „American Journal of International Law" 49, 1955, s. 17.

113 Fourth report on State responsibility, by Mr. James Crawford, Special Rapporteur, Doc. A/CN.4/517 and Add.1 § 21-26. Por. nowsze nawoływania do przygotowania odnośnej konwencji: L.T. Pacht, The case for a convention on state responsibility, „Nordic Journal of International Law” 83, 2014, nr 4, s. 439 n.

114 Ch. Tomuschat, International Law Commission - an outdated institution?, „German Yearbook of International Law" 49, 2006, s. 104. Zob. też J. Katz Cogan, The changing form of the international law commission's work, „AJIL Unbound” 108, 2014, s. 4 n. 
Międzynarodowego może mieć większe znaczenie aniżeli prawo traktatowe ${ }^{115}$. Już wcześniej zauważono ${ }^{116}$, że wiele zależeć będzie od jakości efektów prac Komisji, rozumianej nie tylko jako skrupulatne odzwierciedlenie dotychczasowej praktyki, ale adekwatna odpowiedź na nowe warunki i wyzwania ${ }^{117}$.

Coraz częściej ograniczać się będziemy zatem do kodyfikacji w wersji $l i$ ght, to znaczy „odtłuszczonej”, zawartej w niewiążącym instrumencie, niemniej jednak mającej znaczenie do ustalenia rozumienia prawa międzynarodowego na podobieństwo kodyfikacji traktatowej ${ }^{118}$. Niezależnie od ostatecznej formy działalności KPM formułowanie i usystematyzowanie norm w wersji pisemnej jest przedsięwzięciem, które zapewnia postęp w prawie przez wzmocnienie jego pewności i okazję do wyjaśnienia i rozwijania istniejących już norm, ale też wykrystalizowanie kodyfikowanych reguł w jedną szczegółową formułę może być przeszkodą dla przyszłego rozwoju prawa i jego responsywności względem potrzeb społeczności międzynarodowej ${ }^{119}$.

Brak sukcesów nie stanowi o tym, że idea kodyfikacji realizowanej przez KPM się zdezaktualizowała ${ }^{120}$. Oczywiście zgłaszana pod adresem Komisji krytyka jest bardzo często uzasadniona ${ }^{121}$, ale dla zachowania równowagi trzeba zauważyć, że niekoniecznie musi od razu oznaczać przyjmowanie określonej konwencji. Nawet najbardziej udane kodyfikacje (jak dotycząca prawa traktatów) nie wchodziły w życie natychmiastowo, a poziom ich akceptacji daleki jest od uniwersalnego.

115 D. Caron, The ILC articles on state responsibility: The paradoxical relationship between form and authority, „American Journal of International Law” 96, 2002, nr 4, s. 866.

116 B.G. Ramcharan, The International Law Commission: Its Approach to the Codification and Progressive Development of International Law, The Hague 1977, s. 40.

117 O. Schachter, Law-making in the United Nations, [w:] Perspectives on International Law, red. N. Jasentuliyana, London 1995, s. 134.

118 S. Villalpando, Codification light: A new trend in the codification of international law at the United Nations, „Anuário Brasileiro de Direito Internacional” 8, 2013, nr 2 (15), s. 148.

119 Ibidem, s. 126. W znakomitej analizie, będącej jednocześnie przestrogą przed krytykancką postawą wobec działalności kodyfikacyjnej, prof. Karol Wolfke zwracał uwagę, że „pomimo licznych wpadek i niedociągnięć oraz wręcz porażek prób kodyfikowania nie mogą one być traktowane jako szkodliwe, jako że stanowią one czasem pozytywne, a czasem negatywne - ale zawsze pożyteczne doświadczenia i cenne powiązanie w żmudnym poszukiwaniu prawdziwie obowiązujących i skutecznych norm prawa międzynarodowego" - zob. idem, Can codification of international law be harmful?, [w:] Essays in International Law in Honour of Judge Manfred Lachs, red. J. Makarczyk, The Hague 1984, s. 313-320.

120 Por. G. Nolte, op. cit., s. 783.

121 Oprócz filipiki J. Stone, On the vocation of the International Law Commission, „Columbia Law Review” 57, 1957, s. 48 n. zob. np. J. Dugard, How effective is the International Law Commission in the development of international law? A critique of the ILC on the occasion of its fiftieth anniversary, „South African Yearbook of International Law” 23, 1998, s. 35 n. 


\section{Uwagi końcowe}

Prace Komisji Prawa Międzynarodowego nad kodyfikacją zbrodni przeciwko ludzkości obrazują podstawowe dylematy nad rozwojem prawa międzynarodowego w ogólności, lecz także w ramach międzynarodowego prawa karnego. Nie kwestionując jakości prowadzonych analiz, a doceniając raczej ich przydatność, można spodziewać się, że będą cennym punktem odniesienia nie tylko w dalszych trudach kodyfikacyjnych, ale też w orzecznictwie międzynarodowym. Klaryfikacja i uporządkowanie spojrzenia na zmieniający się stan normatywny jest bardzo potrzebna, pozytywnie przysłuży się praktyce międzynarodowej, nawet jeśli nie należy spodziewać się rychłego wejścia w życie specjalnej konwencji poświęconej zbrodniom przeciwko ludzkości.

\section{Bibliografia}

Abi-Saab G., La Commission du droit international, la codification et le processus de formation de droit international, [w:] Making Better International Law: Proceedings of the United Nations Colloquium on Progressive Development and Codification of International Law, New York 1998.

Ambos K., Treatise on International Criminal Law, t. 2. The Crimes and Sentencing, Oxford 2014.

Basak A., International custom and the experience of Nuremberg, [w:] Essays in Memory of Professor Karol Wolfke, red. B. Krzan („Wroclaw Review of Law, Administration \& Economics” 8, 2018, nr 2).

Bassiouni M.Ch., Crimes Against Humanity: Historical Evolution and Contemporary Application, Cambridge 2011.

Bassiouni M.Ch., Crimes against humanity: The need for a specialized convention, „Columbia Journal of Transnational Law" 31, 1994.

Baxter R.R., The effects of ill-conceived codification and development of international law, [w:] Recueil d'études de droit international en hommage à Paul Guggenheim, Genève 1968.

Bordin F.L., Reflections of customary international law: The authority of codification conventions and ILC Draft Articles in International Law, ICLQ 63, 2014.

Bush J.A., The prehistory of corporations and conspiracy in international criminal law: What Nuremberg really said, „Columbia Law Review” 109, 2009.

Caron D., The ILC articles on state responsibility: The paradoxical relationship between form and authority, „American Journal of International Law” 96, 2002, nr 4.

Clark R.S., Crimes against humanity at Nuremberg, [w:] The Nuremburg Trial and International Law, red. G. Ginsburgs, V.N. Kudriavtsev, The Hague 1990.

Cyprian T., Sawicki J., Prawo norymberskie. Bilans i perspektywy, Warszawa-Kraków 1948.

Cyprian T., Sawicki J., Walka o zasady norymberskie 1945-1955, Warszawa 1956.

Czapliński W., Customary international law as a basis of an individual criminal responsibility, [w:] Prosecuting International Crimes: A Multidisciplinary Approach, red. B. Krzan, Leiden-Boston 2016.

Dinstein Y., Crimes against humanity, [w:] Theory of International Law at the Threshold of the 21st Century: Essays in Honour of Krzysztof Skubiszewski, red. J. Makarczyk, The Hague 1996.

Donnedieu de Vabres H., Le jugement de Nuremberg et le principe de la légalité des délits et des peines, „Revue de Droit Pénal et de Criminologie” 26, 1947, nr 10. 
Doria J., Whether crimes against humanity are backdoor war crimes, [w:] The Legal Regime of the ICC: Essays in Honour of Prof. I.P. Blishchenko, red. J. Doria et al., Leiden-Boston 2009.

Dubler R., Kalyk M., Crimes Against Humanity in the 21st Century: Law, Practice and Threats to International Peace and Security, Leiden-Boston 2018.

Dugard J., How effective is the International Law Commission in the development of international law? A critique of the ILC on the occasion of its fiftieth anniversary, „South African Yearbook of International Law" 23, 1998.

Dupuy P.M., Coutume sage et coutume sauvage, [w:] Mélanges offerts à Charles Rousseau: La communauté international, Paris 1974.

Evans G., Crimes against humanity and the responsibility to protect, [w:] Forging a Convention for Crimes against Humanity, red. L.N. Sadat, Cambridge 2011.

Frulli M., The contribution of international criminal tribunals to the development of international law: The prominence of opinio juris and the moralization of customary law, „The Law \& Practice of International Courts and Tribunals" 14, 2015.

Glaser S., Droit international pénal conventionnel, Bruxelles 1970.

Graven J., Les Crimes contre l'Humanité, „Recueil des Cours de l'Académie de Droit International” $76,1950$.

Hafner G., Is the topic of responsibility of international organizations ripe for codification? Some critical remarks, [w:] From Bilateralism to Community Interest: Essays in Honour of Bruno Simma, red. U. Fastenrath et al., Oxford 2011.

Hannum H., International Law and Cambodian genocide: The sounds of silence, „Human Rights Quarterly"11, 1989.

Hebel H. von, Robinson D., Crimes within the jurisdiction of the Court, [w:] The International Criminal Court: The Making of the Rome Statute: Issues, Negotiations, Results, red. R.S. Lee, The Hague 1999.

Herik L. van den, The decline of customary international law as a source of international criminal law, [w:] Custom's Future: International Law in a Changing World, red. C. Bradley, Cambridge 2016.

Holy K., Prawo międzynarodowe publiczne wobec amnestii, Warszawa 2015.

Hurst C., A plea for the codification of international law on new lines, „Transactions of the Grotius Society" 32, 1946.

Iwanek T., Zbrodnia ludobójstwa i zbrodnie przeciwko ludzkości w prawie międzynarodowym, Warszawa 2015.

Katz Cogan J., The changing form of the International Law Commission's work, „AJIL Unbound” 108, 2014.

Kocot K., Wolfke K., Wybór dokumentów do nauki prawa międzynarodowego, Wrocław-Warszawa 1976.

Kreß C., Garibian S., Laying the foundations for a convention on crimes against humanity: Concluding observations, „Journal of International Criminal Justice” 16, 2018.

Krzan B., Obowiazywanie zasady nulla poena sine lege z perspektywy międzynarodowych trybunałów karnych, [w:] Prawo międzynarodowe: idee a rzeczywistość, red. E. Cała-Wacinkiewicz, Warszawa 2018.

Lamb S, Nullum crimen, nulla poena sine lege in inernational criminal law, [w:] The Rome Statute of The International Criminal Court: A Commentary, t. 1, red. A. Cassese, P. Gaeta, J.R.W.D. Jones, Oxford 2002.

Lauterpacht E., The Life of Hersch Lauterpacht, Cambridge 2010.

Lauterpacht H., Codification and development of international law, „American Journal of International Law" 49, 1955.

Lingen K. von, Defining crimes against humanity: The contribution of the United Nations War Crimes Commission to international criminal law, [w:] Historical Origins of International Criminal Law, t. 1, red. M. Bergsmo et al., Brussels 2014.

Studia nad Autorytaryzmem i Totalitaryzmem 42, nr 2, 2020

(C) for this edition by CNS 
Luban D., A theory of crimes against humanity, „Yale Journal of International Law” 29, 2004.

Meron Th., Customary humanitarian law: From the academy to the courtroom, [w:] idem, The Making of International Criminal Justice. A View from the Bench: Selected Speeches, Oxford 2011.

Mettraux G., The definition of crimes against humanity and the question of a "policy" element, [w:] Forging a Convention for Crimes Against Humanity, red. L.N. Sadat, Cambridge 2011.

Murphy S.D., Foreword, „Journal of International Criminal Justice” 16, 2018.

Nolte G., The International Law Commission facing the second decade of the twenty-first century, [w:] From Bilateralism to Community Interest: Essays in Honour of Bruno Simma, red. U. Fastenrath et al., Oxford 2011.

Nouwen S.M.H., Is there something missing in the proposed convention on crimes against humanity? A Political question for states and a doctrinal one for the International Law Commission, „Journal of International Criminal Justice” 16, 2018.

Ohlin J.D., Organizational criminality, [w:] Pluralism in International Criminal Law, red. E. van Sliedregt, S. Vasiliev, Oxford 2014.

O'Keefe R., International Criminal Law, Oxford 2015.

O'Keefe R., The ILC's contribution to international criminal law, „German Yearbook of International Law" 49, 2006.

Orentlicher D., Immunities and amnesties, [w:] Forging a Convention for Crimes Against Humanity, red. L.N. Sadat, Cambridge 2013.

Pacht L.T., The case for a convention on state responsibility, „Nordic Journal of International Law” 83, 2014, nr 4.

Płachta M., Międzynarodowy Trybunat Karny, Kraków 2004.

Ramcharan B.G., The International Law Commission: Its Approach to the Codification and Progressive Development of International Law, The Hague 1977.

Relva H.A., Three propositions for a future convention on crimes against humanity: The prohibition of amnesties, military courts, and reservations, „Journal of International Criminal Justice” 16, 2018.

Robinson D., Defining “crimes against humanity” at the Rome Conference, „American Journal of International Law" 93, 1999.

Sadat L.N., A comprehensive history of the proposed international convention on the prevention and punishment of crimes against humanity', [w:] Forging a Convention for Crimes Against Humanity, red. L.N. Sadat, Cambridge 2013.

Sadat L.N., A new global treaty on crimes against humanity future prospects, [w:] Arcs of Global Justice: Essays in Honour of William A. Schabas, red. M.M. deGuzman, D.M. Amann, Oxford 2018.

Sadat L.N., Towards a new global treaty on crimes against humanity, [w:] For the Sake of Present and Future Generations: Essays on International Law, Crime and Justice in Honour of Roger S. Clark, red. S. Linton, G. Simpson, W.A. Schabas, Leiden-Boston 2015.

Schabas W., Unimaginable Atrocities: Justice, Politics and Rights at the War Crimes Tribunals, Oxford 2012.

Schabas W.A., Prevention of crimes against humanity, „Journal of International Criminal Justice” $16,2018$.

Schachter O., Law-making in the United Nations, [w:] Perspectives on International Law, red. N. Jasentuliyana, London 1995.

Schwelb E., Crimes against humanity, „British YearBook of International Law” 23, 1946.

Sinclair I., The International Law Commission, Cambridge 1987.

Sliedregt E. van, Criminalization of crimes against humanity under national law, „Journal of International Criminal Justice" 16, 2018.

Stahn C., A Critical Introduction to International Criminal Law, Cambridge 2018.

Studia nad Autorytaryzmem i Totalitaryzmem 42, nr 2, 2020

(C) for this edition by CNS 
Stanton G.H., Why the world needs an international convention on crimes against humanity, [w:] Forging a Convention for Crimes Against Humanity, red. L.N. Sadat, Cambridge 2011.

Stone J., On the vocation of the International Law Commission, „Columbia Law Review” 57, 1957. Tams Ch., Enforcing Obligations Erga Omnes in International Law, Cambridge 2005.

Thirlway H., International Customary Law and Codification: An Examination of the Continuing Role of Custom in the Present Period of Codification of International Law, Leiden 1972.

Tladi D., Complementarity and cooperation in international criminal justice: Assessing initiatives to fill the impunity gap, ISS Paper 277, 2014.

Tomuschat Ch., L'exemple de la Commission du droit international, [w:] SFDI, Colloque d'Aix-enProvence, La codification du droit international, Paris 1993.

Tomuschat Ch., The International Law Commission — an outdated institution?, „German Yearbook of International Law" 49, 2006.

Villalpando S., Codification light: A new trend in the codification of international law at the United Nations, „Anuário Brasileiro de Direito Internacional” 8, 2013, nr 2 (15).

Waszczyński J., Zbrodnie przeciw ludzkości: narodziny i rozwój pojęcia, „Palestra” 30, 1986, nr 10 11 (346-347).

Wilt H. van der, State practice as element of customary international law: A white knight in international criminal law?, „International Criminal Law Review” 20, 2020.

Wolfke K., Can codification of international law be harmful?, [w:] Essays in International Law in Honour of Judge Manfred Lachs, red. J. Makarczyk, The Hague 1984. 